\title{
The Ten-Minute Vocabulary Tests for Quick and Approximate Estimates of General English Ability of Japanese EFL Learners IV
}

\author{
KATAGIRI Kazuhiko \\ Reitaku University
}

\begin{abstract}
In Katagiri (2001a), three Forms of a new vocabulary test based on word difficulty order with only 32 items which can be conducted in less than 10 minutes were developed for quick and approximate estimates of examinees' general English ability. Through Katagiri (2001b, 2002b), the concurrent validity and the reliability of the three Forms were confirmed among senior high school students, and the three Forms were confirmed as parallel tests with one another.

In this study, the author, first, examines the concurrent validity and the reliability of the three Forms among university students, using TOEIC as a target of concurrent validity. He, then, attempts to create mathematical formulas to convert the scores of each Form into TOEIC scores.

One hundred seventy-five freshmen at university took the three Forms of the new vocabulary tests and TOEIC IP. Significant middle correlations were narrowly confirmed between each Form and TOEIC; a middle-high IRT reliability was also narrowly affirmed on each Form. Using simple regression analysis, mathematical formulas which convert the raw scores of each Form into TOEIC scores was created.

It was concluded that (1) the concurrent validity and the reliability of each Form were also confirmed among university students as tests for quick and approximate estimates of general English ability, and (2) the conversion formulas from the scores of each Form into TOEIC scores were calculated and shown with the means of errors, which must be taken into consideration when they are utilized.
\end{abstract}

\section{INTRODUCTION}

This research is the fifth study of a larger project that is to develop quick-andapproximate-estimating English tests with some parallel Forms for Japanese EFL learners (especially targeting senior high school students), using Item Response Theory (IRT), which can produce absolute scores comparable with the examinees' former or following test scores like TOEFL or TOEIC scores. These types of tests are 
needed by many English teachers at junior/senior high schools, junior colleges, and universities, as well as language educational researchers. At some universities, placement tests are needed, which can be conducted with less time-consuming methods and are less burdensome for the teachers. Moreover, in these days of megaand fierce-competition for universities to survive, at some universities or in certain departments, it is important to know the progress of each student's English ability after their entrance to the universities. Language educational researchers often need tests, which can be conducted in a very short time and with less burden on the subjects, to realize the subjects' English ability quickly, when they carry out their educational research. These are the reasons for the project being conducted. The author would like the new tests to be really practical and available at school and university level in Japan even if the accuracy of the estimates deteriorates to some extent, and even if the new tests have some small problems from the viewpoint of language testing theory.

The purposes of this fifth study are: (1) to examine the concurrent validity and the reliability of each Form of the new vocabulary tests (VTs) developed in Katagiri (2001a) as quick-and-approximate-estimating English tests, using Japanese university students as subjects, and (2) to attempt to create mathematical formulas to convert the scores of each Form into TOEIC scores.

\section{REVIEW}

Through Katagiri (2000, 2001a), previous research studies related to the following two points were reviewed in detail (Laufer 1992, Kobayashi 1995, Yamauchi 1995, Takashima 1998, Yamaguchi 1998, Meara and Fitzpatrick 2000, Read 2000; Nation 1990, Aizawa 1998, Mochizuki 1998): 1) why was the way of measuring knowledge of vocabulary chosen for quick and approximate estimates of general English ability?; and 2) what kind of and which existing vocabulary test would work the best for quick and approximate estimates of general English ability of Japanese EFL learners? In this paper, these reviews were not produced in detail because of space limitation, but it was concluded that (1) vocabulary knowledge has been considered one of the major components of L2 ability, and many previous studies showed that vocabulary knowledge is related to general English ability; and that (2) the latest Mochizuki's (1998) Vocabulary Size Test (VST) appeared best utilized for Japanese high school students. The author, then, will survey his four previous studies briefly here.

In the first study, Katagiri (2000), it was found that (1) Mochizuki's VST is suitable as a quick and approximate indicator of general English ability and that (2) the written VST may be more efficient than the listening VST. 
Table 1

The Rank-Order of Word Difficulty and (Word Difficulty = Item Measures)

\begin{tabular}{|c|c|c|c|}
\hline $\begin{array}{c}\text { Item } \\
\text { Number }\end{array}$ & Form I & Form II & Form II \\
\hline Q1 & $1(-2.23)$ & $2(-2.23)$ & $3(-2.18)$ \\
\hline Q2 & $6(-1.83)$ & $5(-1.96)$ & $4(-2.11)$ \\
\hline Q3 & $7(-1.76)$ & $8(-1.63)$ & $9(-1.56)$ \\
\hline Q4 & $12(\cdot 1.31)$ & $11(-1.52)$ & $10(-1.52)$ \\
\hline$\cdot$ & $\cdot$ & $\cdot$ & $\cdot$ \\
\hline$\cdot$ & $\cdot$ & $\cdot$ & $\cdot$ \\
\hline$\cdot$ & $90(1.61)$ & $89(1.56)$ & $88(1.51)$ \\
\hline Q30 & $91(1.61)$ & $92(1.63)$ & $93(1.80)$ \\
\hline Q31 & $96(1.91)$ & $95(1.91)$ & $94(1.81)$ \\
\hline Q32 & $-(0.04)$ & $-(0.03)$ & $-(0.03)$ \\
\hline Mean & $-(1.05)$ & $-(1.06)$ & $-(1.06)$ \\
\hline S.D. & & & \\
\hline
\end{tabular}

In the second study, Katagiri (2001a), (1) using FACETS (Linacre 1989; a Rasch measurement computer program), test item analyses were conducted for each of 210 items of Mochizuki's VST; (2) misfitting items, overfitting items, and lowdiscriminant-power items were identified and eliminated from the 210 items, and 102 items were left; and (3) the remaining test items were ordered according to word difficulty (item measures), and then, beginning with the easiest item (the least in the value of item measures), three test items which had almost the same item difficulty were chosen and divided into three sets (Form I, Form II, and Form III), following Table 1. Each set was made up of the same number of test items (32), which had almost the same item difficulty as the respective test item of the other sets. The Q1-item is the easiest; the Q32 the most difficult. The difficulty of the test items is continuous from the Q1-item (the easiest) to the Q32-item (the most difficult). In this way, new vocabulary tests based on word difficulty order with only 32 items which can be conducted in less than 10 minutes were developed for quick and approximate estimates of examinees' general English ability; the new vocabulary tests had three theoretical parallel Forms. The three Forms are shown in the Appendix.

In the third and fourth studies, Katagiri (2001b) and Katagiri (2002b), using senior high school students as subjects, the author examined the concurrent validity and the reliability of each Form of the new vocabulary tests as quick-and- 
approximate-estimating English tests, and also examined whether the three Forms are actually parallel with one another. It was concluded that: (1) the concurrent validity and the reliability of each Form were confirmed as the tests for quick and approximate estimates of general English ability; and that (2) Form I , Form II, and Form III were affirmed as actual parallel tests with one another. The three Forms were given to readers with the understanding that these new tests can not be used as high stakes tests because these are for quick and appropriate estimates and that their Standard Errors of Measurement (SEMs) are 2.0-2.3.

In this study, the author (1) examined the concurrent validity and the reliability when university students took the new VTs, and (2) tried to convert the scores of the new VTs into TOEIC scores.

\section{RESEARCH DESIGN}

\subsection{Purposes}

The purposes of this study are:

(1) to examine the concurrent validity and the reliability of each Form of the new vocabulary tests developed in Katagiri (2001a) as quick-and-approximateestimating English tests, when Japanese university students take them.

(2) to attempt to create a mathematical formula to convert the scores of the new tests into TOEIC scores.

\subsection{Subjects}

One hundred seventy-five freshmen at the faculty of foreign languages at a university, whose majors were German, Chinese or Japanese, participated in this experiment. Since this experiment was conducted in April, they had just started taking classes at the university.

\subsection{Materials}

Two kinds of tests were prepared: the three Forms of the new vocabulary tests developed in Katagiri (2001a) and TOEIC Institutional Program (IP). The three Forms are shown in the Appendix. TOEIC was chosen as the target of the concurrent validity for the following reasons: (1) TOEIC provided us with absolute scores, using the IRT three-parameter-logistic model; (2) TOEIC consisted of a 100-item listening section and a 100-item reading section, which seemed reasonable numbers and proper components for test items; and (3) TOEIC was one of the most well-known and well-used tests for university students and adults in Japan.

\subsection{Experiment}

The subjects first took the TOEIC IP for two hours one day. Several days after 
that, they took all the three Forms (first, Form I ; then, Form II ; lastly, Form III) of the new 32-item vocabulary tests successively with a time limitation of 10 minutes for each Form, so it took 30 minutes in total.

\subsection{Data Analyses}

Analyses were conducted according to the following procedure:

(1) The descriptive statistics for each Form and TOEIC were calculated.

(2) To examine the test properties, using FACETS, on both the person measures (the scores on Rasch measurement) and the item measures (the item difficulty on Rasch measurement), (i) means of standard errors (S.E.s), (ii) standard deviations (S.D.s) of the S.E.s, (iii) separation indices ("a measure of the spread of the estimates relative to their precision" Linacre 1989: 73), (iv) IRT reliabilities ("the ratio of 'True variance' to 'Observed variance."' ibid.), and (v) (only on the item measures) a mean of the classical indices of item discrimination (that is, point-biserial correlation coefficients), using Fisher's $z$-transformations, were calculated.

(3) To examine the concurrent validity, Pearson's product moment correlation coefficients were calculated between the raw scores of each Form and the TOEIC scores.

(4) Using simple regression analysis, mathematical formulas which convert the raw scores of each Form into TOEIC scores, that is, the formulas which represent regression lines were calculated.

\section{RESULTS AND DISCUSSION}

\subsection{The Descriptive Statistics and Various Indices Produced by FACETS}

Means and standard deviations of each Form and TOEIC are indicated in Table 2. We see the differences of the means between any two Forms among the three were less than Standard Errors of Measurement (2.3), which is shown later in Table 4.

Table 2 Means, S.D.s, Maximums, and Minimums of Each Form and TOEIC

\begin{tabular}{|c|c|c|c|c|}
\hline & Form I & Form II & Form II & TOEIC \\
\hline Mean & 18.4 & 20.3 & 19.1 & 351.5 \\
\hline S.D. & 4.3 & 4.9 & 4.5 & 81.4 \\
\hline Max. & 28 & 31 & 28 & 650 \\
\hline Min. & 7 & 8 & 3 & 180 \\
\hline
\end{tabular}


Table 3 Various Indices Produced by FACETS on Each Form of the New 32-Item VTs

\begin{tabular}{|c|c|c|c|c|c|c|}
\hline & & $\begin{array}{l}\text { Mean of } \\
\text { S.E.s }\end{array}$ & $\begin{array}{l}\text { S.D. of } \\
\text { S.E.s }\end{array}$ & $\begin{array}{l}\text { Separation } \\
\text { Index }\end{array}$ & $\begin{array}{c}\text { IRT } \\
\text { Reliability }\end{array}$ & $\begin{array}{c}\text { Mean of } \\
\text { Point-Biserial } \\
\text { Correlations } \\
\text { using Fisher's } \\
\text { z-transformation }\end{array}$ \\
\hline セ & Person Measures & 0.43 & 0.03 & 1.57 & 0.71 & - \\
\hline D. & Item Measures & 0.20 & 0.05 & 6.71 & 0.98 & 0.22 \\
\hline 曰 & Person Measures & 0.44 & 0.07 & 1.81 & 0.77 & - \\
\hline 望 & Item Measures & 0.20 & 0.08 & 5.75 & 0.97 & 0.26 \\
\hline 目 & Person Measures & 0.44 & 0.04 & 1.64 & 0.73 & - \\
\hline 政 & Item Measures & 0.20 & 0.04 & 6.67 & 0.98 & 0.24 \\
\hline
\end{tabular}

Various indices on each Form produced by FACETS are shown in Table 3. The smaller standard errors (S.E.s) mean a better measurement with less errors; the larger person separation index indicates a better spread of the estimates of the person measures relative to their S.E.s; a higher IRT reliability indicates a higher ratio of "true variance" to "observed variance;" the higher point-biserial correlations indicate higher item discrimination powers of the test items. We cannot obtain both less number of test items (less time-consuming) and less errors of measurement. Still, all the person separation indices of the three Forms had more than 1.5, which means that the spread of the estimates of the person measures was more than the errors (S.E.s), and IRT reliability was more than 0.70 . It is well known that the more test items there are, the higher reliability the test form will obtain as indicated by the Spearman-Brown Prophecy Formula. Therefore, the author judged these values (person separation indices and IRT reliability) as acceptable, considering the new 32-item VTs should be for quick and approximate estimates. As for means of item discrimination powers, these values were satisfied, especially taking only 10 -minute tests into account, since they were over 0.20 .

SEMs were calculated using S.D.s of each Form shown in Table 2 and IRT reliability on person measures shown in Table 3. SEMs, when senior high school students took each Form, were 2.0-2.4 (Katagiri 2001b, 2002b); similar values were

Table 4 Standard Errors of Measurement (SEMs) of Each Form

\begin{tabular}{|c|c|c|c|}
\hline & Form I & Form II & Form III \\
\hline SEM & 2.3 & 2.3 & 2.3 \\
\hline
\end{tabular}


obtained. In this section, it was concluded from these various indices that the test properties of all the Forms were satisfied as quick-and-approximate-estimating English tests.

\subsection{Examining the Concurrent Validity}

Scatter plots of the raw scores of each Form and the TOEIC scores are illustrated in Figures 1, 2, and 3; correlation coefficients between them are shown in Table 5. Unexpectedly, these correlation coefficients were not very high; the coefficients of determination $\left(\mathrm{r}^{2} \times 100[\%]\right)$ were $20 \%-23 \%$, which means that the variance of the new 32 -item VTs accounts for approximately $20 \% \cdot 23 \%$ of the variance

Figure 1

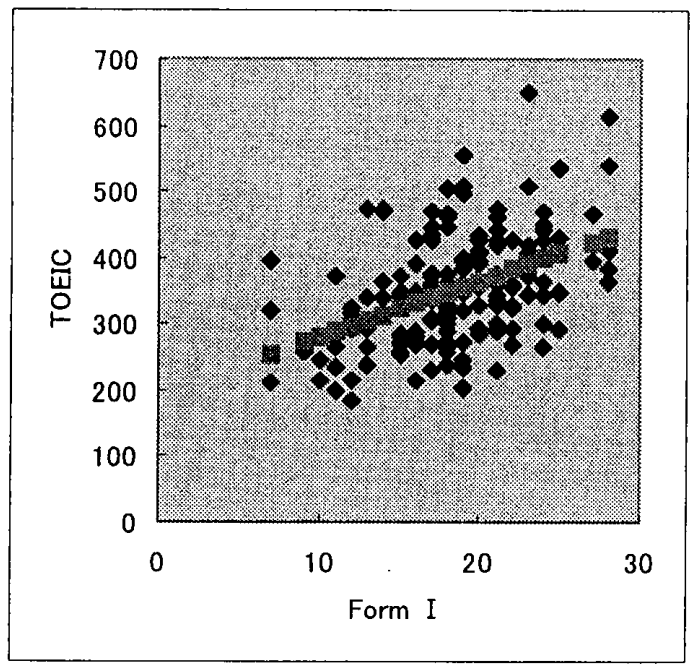

\section{Figure 2}

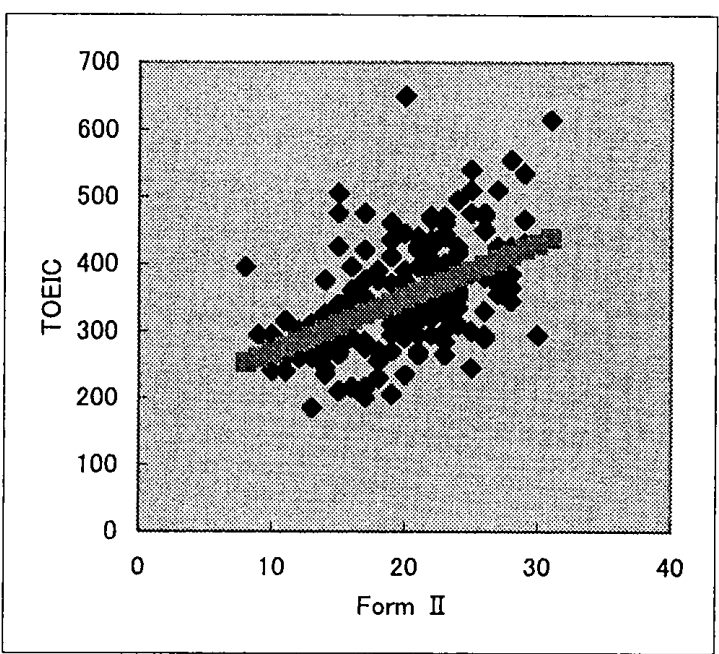

Figure 3

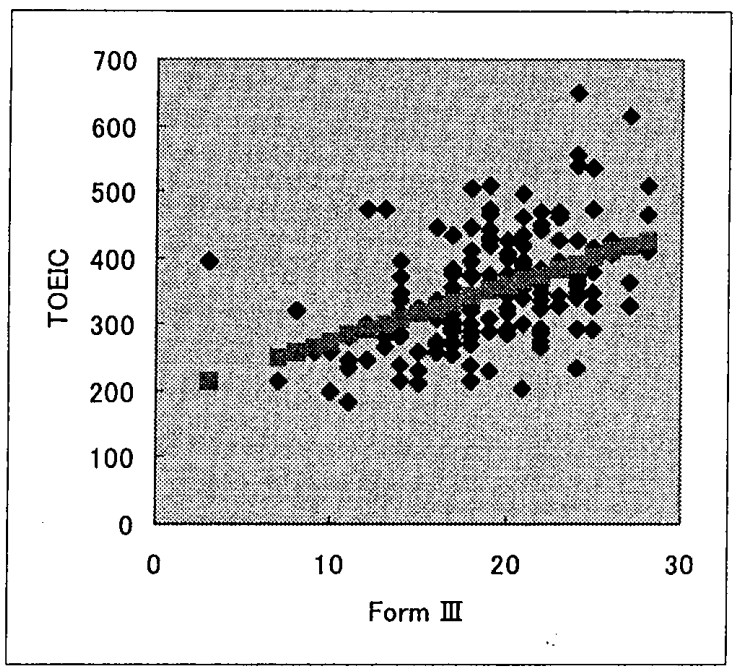


Table 5 Correlations Between Each Form and TOEIC

\begin{tabular}{|c|c|c|c|}
\hline & Form I & Form II & Form III \\
\hline TOEIC & $\mathbf{r}=0.45^{* * *}$ & $\mathrm{r}=0.48^{* * *}$ & $\mathbf{r}=0.46^{* * *}$ \\
\hline
\end{tabular}

of the TOEIC scores. Although these values were not very high nor very satisfactory, the author judged that the concurrent validity of the new 32-item VTs was narrowly affirmed, taking into account that the new 32-item VTs were 10-minute tests for quick and approximate estimates and that suggestions of improving the new $32 \cdot$ item VTs for the future research were given later to increase validity and reliability.

\subsection{Proportions Correct of Each Test Item}

Proportions correct of each test item were shown in Figures 4, 5, and 6. Theoretically, declining linear regressions should be found (See Table 1). Although the actual declining linear regressions were not as clear as ideal types, it was affirmed that item difficulty of the larger item number tended to be the more difficult. This means that the theoretical test structure shown in Table 1 worked effectively, also when university students took the tests.

\section{Figure 4}

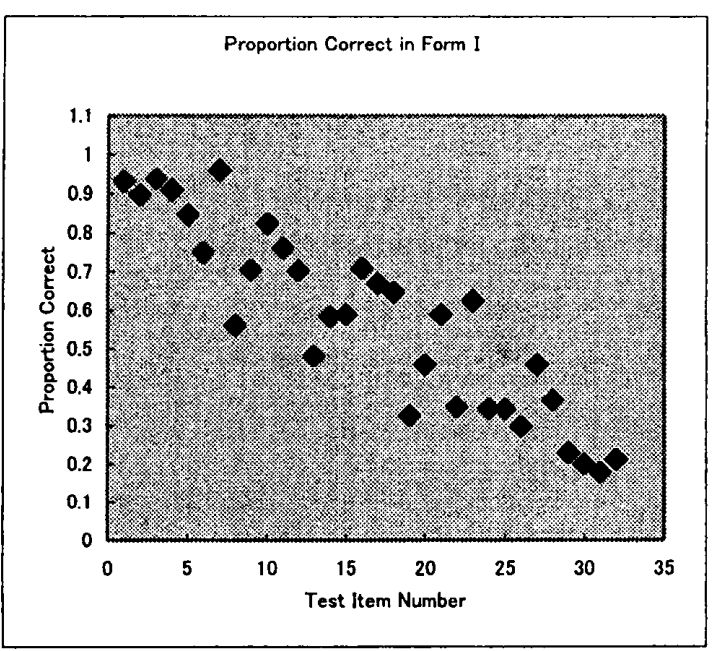

Figure 5

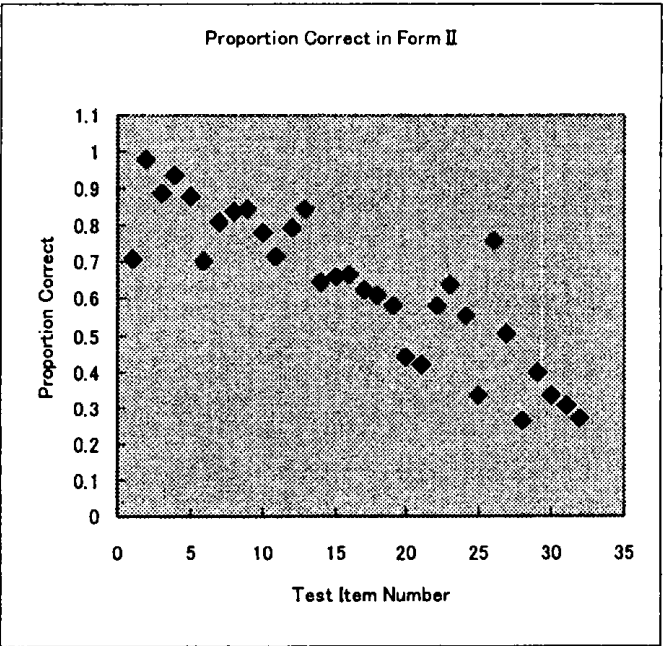




\section{Figure 6}

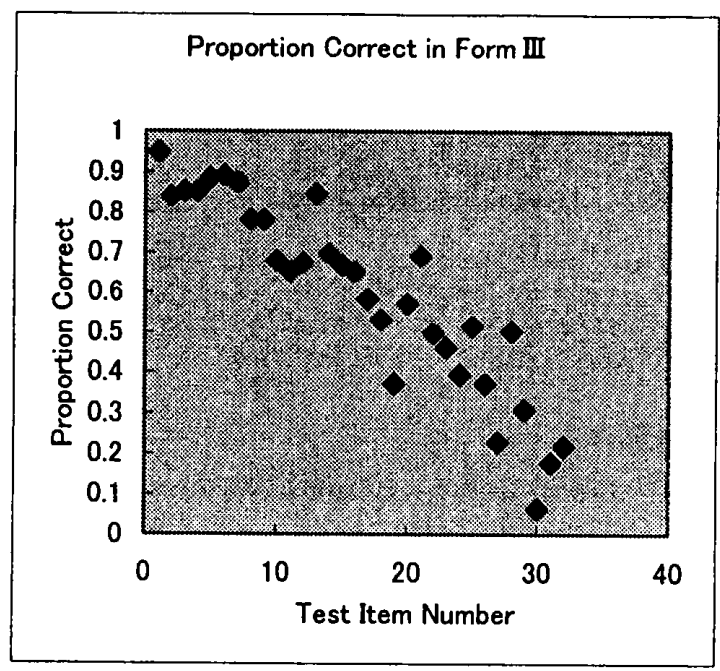

\subsection{Conversion Formula}

Each regression line of the three Forms and the TOEIC are indicated in Figures 1,2, and 3. Using simple regression analysis, mathematical formulas which convert the raw scores of each Form into TOEIC scores, that is, the formulas which represent regression lines were calculated:

(1) Form I : TOEIC $=8.4 \times$ Form I +196.5

$$
\text { Mean of errors } \pm 56.2 ; \quad \text { S.D. of errors } 46.0 ; \quad r^{2}=0.20
$$

(2) Form II : TOEIC $=8.1 \times$ Form II +187.7

$$
\text { Mean of errors } \pm 55.0 ; \quad \text { S.D. of errors } 45.0 ; \quad r^{2}=0.24
$$

(3) Form III : TOEIC $=8.4 \times$ Form III +191.8

$$
\text { Mean of errors } \pm 54.9 ; \quad \text { S.D. of errors } 46.4 ; \quad r^{2}=0.22
$$

It was a corollary of being parallel tests that these three regression lines were almost the same. Since the proper fit of these models is not adequate $\left(r^{2}=0.20 \cdot 0.24\right)$, mean of errors (mean of the absolute values of residuals from the theoretical values) should be taken into consideration when these conversion formulas are used.

The expected TOEIC score would be approximately 190 points even if the new VT score was 0 points, but nobody has obtained 0 points yet. As shown in Table 2, the minimum scores of Form I and Form II are seven or eight points. The reason why the minimum score of Form III is three, which is much less than the other Forms, seemed because a few of the subjects seemed bored or tired from answering the questions of the tests in which they had to take Form I, Form II, and From III successively. Therefore, it seems that we do not have to worry about the case of 
obtaining 0 points. On the other hand, the maximum of the expected TOEIC score would be $446-465$ points even if the new VT score was the full score, 32 points. Still, 24 students obtained 465 points or over in the TOEIC. This (ceiling effect) could be considered the reason why the correlation coefficients were not high enough. Since it was reported that the average score of Japanese university students in the TOEIC was 428 points (TOEIC 2000), the new VTs should be improved so that their ceilings can be much higher.

\subsection{Suggestions for Improvements in Future Research}

In order to increase the correlation coefficients between each Form and the TOEIC, to make the proper fit of the models better, and to make each Form have a much wider range of expected TOEIC scores, the following two improvements are suggested for future research to revise new VTs developed in Katagiri (2001a). One is that, the number of test items should be increased dramatically, for example, from 32 to 60 so that the ceiling effect will be eliminated and that reliability will be increased. Actually almost all of the examinees finished the 32-item VTs in less than 10 minutes (approximately seven or eight minutes), 60-item VTs could probably be administered in 15 minutes. The other is that, for developing new VTs, in the first stage, the basic data of word difficulty (test item difficulty) of each word should also be collected from university students (higher ability EFL learners). In Katagiri (2000), the basic data to understand word difficulty was obtained only from first-year and third-year senior high school students. Although, in the pure model of Item Response Theory, word difficulty (test item difficulty) is estimated and possess the property of invariance (that is, sample-free item calibration), in reality, estimated word difficulty appears to be influenced by the collecting data sample.

As indicated in Figures 1, 2, and 3, some students whose plots were far from the regression lines did not fit the model, which means that these students' English ability cannot be estimated accurately from the vocabulary tests. For future research, after solving the problem of the ceiling effect, the author must investigate what kind of learners they are and how they have been learning English. The percentage of learners whose English ability cannot be estimated accurately from the vocabulary tests should be investigated to determine if the percentage is low and to re-verify the rationale of inferring Japanese EFL learners' English ability through measuring their vocabulary knowledge.

\section{CONCLUSION}

It was concluded that:

(1) The concurrent validity and the reliability of each Form, when Japanese 
university students took it, were narrowly confirmed as the tests for quick and approximate estimates of general English ability.

(2) The conversion formulas from the scores of each Form into TOEIC scores were calculated and shown with the means of errors, which must be taken into consideration when they are utilized.

(3) Two major improvements were suggested for future research to recreate better vocabulary tests for quick and approximate estimates.

Since the new vocabulary tests are for quick and approximate estimates, these can not be used as high stakes tests. SEMs were 2.3 in any Form; the score differences less than 2.3 between pretest and posttest should be regarded within errors when two different Forms are used as pretest and posttest.

\section{NOTES}

* The results of this study were orally presented at the $25^{\text {th }}$ annual meeting of Kanto-Koshin-Etsu English Language Education Society held in Niigata on August 18, 2001, and this paper is based on part of my Ph.D. dissertation submitted to Tokyo Gakugei University.

* I wish to thank Prof. David WINIARSKI at Tokyo National College of Technology for his advice on an earlier draft of this paper.

\section{REFERENCES}

Aizawa, K. 1998. A Study of Incidental Vocabulary Learning Through Reading by Japanese EFL Learners. Unpublished doctoral dissertation. Tokyo: Tokyo Gakugei University.

Bachman, L. F. 1990. Fundamental Considerations in Language Testing. Oxford: Oxford University Press.

Bachman, L. F. and Palmer, A. S. 1996. Language Testing in Practice. Oxford: Oxford University Press.

Henning, G. 1987. A Guide to Language Testing. Boston: Heinle and Heinle Publishers.

Katagiri, K. 2000. "Quick and Rough Estimates of General English Ability, Using Mochizuki's Vocabulary Size Test for Japanese EFL Learners" The Japan Language Testing Association Journal, 3, 83-99.

Katagiri, K. 2001a. "The ten-minute vocabulary tests for quick and rough estimates of general English ability of Japanese EFL learners I ." The Japan Language Testing Association Journal, 4, 1-20.

Katagiri, K. 2001b. "The ten-minute vocabulary tests for quick and rough estimates 
of general English ability of Japanese EFL learners II." The Bulletin of the Kanto-Koshin-Etsu English Language Education Society, 15, 39-58.

Katagiri, K. 2002a. Developing the Ten-Minute Vocabulary Tests for Quick and Approximate Estimates of General English Ability of Japanese EFL Learners. Unpublished doctoral dissertation. Tokyo: Tokyo Gakugei University.

Katagiri, K. 2002b. "The ten-minute vocabulary tests for quick and approximate estimates of general English ability of Japanese EFL learners III." To appear in Reitaku University Journal , 74.

Kobayashi, T. 1995. "Goi no Dokukai ni Oyobosu Eikyo [The Effect of Vocabulary to Reading Comprehension]." The Bulletin of the Chubu English Language Education Society, 25, 79-84.

Laufer, B. 1992. "How much lexis is necessary for reading comprehension?" In Arnaud, P. J. L. and Bejoint, H. (eds.), Vocabulary and Applied Linguistics. London: Macmillan, $126 \cdot 132$.

Linacre, J. M. 1989. A User's Guide to Facets. ver. 3.1. Chicago: MESA Press.

Meara, P. and Fitzpatrick, T. 2000. "Lex30: an improved method of assessing productive vocabulary in an L2. " System, 28, 1, 19-30.

Mochizuki, M. 1998. "Nihonjin Eigo Gakusyusya no tameno Goi Saizu Tesuto [A Vocabulary Size Test for Japanese Learners of English]" The Institute for Research in Language Teaching Bulletin, 12, 27-53.

Nation, P. 1990. Teaching and Learning Vocabulary. New York: Newbury House Publishers.

Ohtomo, K. 1996. Koumoku Ohto Riron Nyuumon [An Introduction to Item Response Theory]. Tokyo: Taishukan Press.

Read, J. 1993. "The development of a new measure of L2 vocabulary knowledge." Language Testing, 10, 3, 355-371.

Read, J. 2000. Assessing Vocabulary. Cambridge: Cambridge University Press.

Takashima, H. 1998. "Accuracy of spoken word recognition as a predictor of listening comprehension for Japanese learners of English." ARELE, 9, 87-95.

TOEIC. 2000. Data \& Analysis. Tokyo: The Institute for International Business Communication.

Yamaguchi, T. 1998. "Effects of training in rapid word recognition on listening comprehension: an analysis of translation-task data from Japanese EFL learners." Hiroshima Daigaku Daigakuin Kyouikugaku Kenkyu-ka Shuushi Ronbun Shuu [A Collection of M.A. Theses Abstracts of the Faculty of Education, Hiroshima University], 125-128.

Yamauchi, M. 1987. Shinri/Kyoiku no tameno Toukeihou [Statistics of Psychology and Education]. Tokyo: Science Press.

Yamauchi, Y. 1995. Inferencing Strategies of Unknown Words in EFL Reading Comprehension. Unpublished M.A. Thesis. Tokyo: Tokyo Gakugei University. 


\section{APPENDIX}

\section{FORM I}

日本語の意味を表す英語を (a)〜 (f)の中から選び，その番号を解答用紙に記入せよ。

I -Question 1. 民主主義
(a) approval
(b) contract
(c) democracy
(d) institution
(e) recall (f) wheat

I -Question 2. 救う, 救出する
(a) attract
(b) discover
(c) observe
(d) pour
(e) recognize (f) save

I-Question 3. 儀式
(a) apparatus
(b)boundary
(c) ceremony
(d) emergency
(e) horizon (f) sympathy

I -Question 4. 哚くする，濃くする
(a) deepen
(b) dissatisfy
(c) imprint
(d) pinpoint
(e) shuffle (f) sidestep

I -Question 5. 広くする
(a) bump
(b) confront
(c) graduate
(d) promote
(e) scan (f) widen

I-Question 6. 単数の
(a) administrative
(b) atomic
(c) concrete
(d) frank
$\begin{array}{ll}\text { (e) linguistic (f) singular } & \end{array}$

I-Question 7. 経済的に, 節約して
(a) aptly
(b) economically
(c) fundamentally
(d) genuinely
(e) immensely (f) radically

I-Question 8. 可能性のある
(a) confident
(b) mechanical
(c) odd
(d) potential
(e) splendid (f) unusual

I -Question 9. （特に小型の）船舶
(a) cereal
(b) craft
(c) deposit
(d) pastry
(e) portion (f) registration

I-Question 10. 小さな包み
(a) bid
(b) certificate
(c) evolution
(d) lane
(e) packet (f) poll

I -Question 11. 酒類
(a) consciousness
(b) fellowship
(c) liquor
(d) observer
(e) saucer (f) vitality

I-Question 12. 検查官, 監查人
(a) armor
(b) brim
(c) inspector
(d) integration
(e) psychiatry (f) supplement

I -Question 13. （ボートより大きい）船
(a) barn
(b) existence
(c) heap
(d) manufacturer
(e) mist (f) vessel

I -Question 14. 設備, 備品
(a) account
(b) courage
(c) equipment
(d) factor
(e) flood (f) lack

I -Question 15. 食事をする
(a) admit
(b) deny
(c) dine
(d) fell
(e) inquire (f) rescue 
I -Question 16. たか
(a) adage
(b) aspen
(c) cub
(d) flair
(e) hawk (f) tract

I-Question 17. 毎年の，年間の
(a) annual
(b) constant
(c) deaf
(d) identical
$\begin{array}{ll}\text { (e) modest } & \text { (f) recent }\end{array}$

I-Question 18. 注射
(a) correction
(b) disposition
(c) heir
(d) injection
(e) moss (f) recollection

I -Question 19. ただ〜だけ，単に
(a) gradually
(b) nearby
(c) necessarily
(d) occasionally
(e) solely (f) technically

I -Question 20. 通路，通行
(a) climate
(b) factory
(c) law
(d) link
(e) passage (f) view

I -Question 21. 遺伝子の, 遺伝学的な
(a) adjective
(b) collective
(c) considerate
(d) eloquent
(e) frantic (f) genetic

I-Question 22. 肺炎
(a) clan
(b) granite
(c) paralysis
(d) pneumonia
(e) rouge (f) sabotage

I -Question 23. がらくた，くず物
(a) cadence
(b) composure
(c) hue
(d) influx
$\begin{array}{lll}\text { (e) junk } \quad(f) \text { quirk } & \end{array}$

I-Question 24. 腐る，朽ちる
(a) decay
(b) distribute
(c) fasten
(d) fold
(e) isolate (f) revise

I-Question 25. 肉, 肉体
(a) beach
(b) curl
(c) economy
(d) flesh
(e) glory
(f) worker

I-Question 26. じゃまする，妨げる
(a) conclude
(b) hinder
(c) murmur
(d) reconcile
$\begin{array}{ll}\text { (e) stagger (f) weave } & \end{array}$

I-Question 27. 手がかり
(a) bullet
(b) clue
(c) equator
(d) facility
(e) lap (f) opponent

I -Question 28. まひ，中風
(a) pneumonia
(b) sabotage
(c) granite
(d) clan
(e) rouge (f) paralysis

I-Question 29. 関連，適切さ
(a) deduction
(b) dwarf
(c) limestone
(d) plague
(e) plank (f) relevance

I -Question 30. 弁解する，嘆願する
(a) arouse
(b) clash
(c) invade
(d) plead
(e) prompt (f) soak

I -Question 31. 訂正
(a) heir
(b) recollection
(c) injection
(d) moss
(e) disposition (f) correction

I-Question 32. 幻覚

(a) adversary (b) chronicle (c) exploitation (d) hallucination (e) pesticide (f) retrospect 


\section{FORM II}

日本語の意味を表す英語を（a）(f)の中から選び，その番号を解答用紙に記入せよ。

\section{II -Question 1. 望遠鏡}
(a) cube
(b) kilometer
(c) license
(d) microscope
(e) studio (f) telescope

II -Question 2. 説明
(a) billion
(b) bundle
(c) explanation
(d) flavor
(e) lightning (f) psychology

II -Question 3. 意見，眺める
(a) climate
(b) factory
(c) law
(d) link
(e) passage (f) view

II-Question 4. 認めること，承認
(a) admission
(b) bull
(c) feast
(d) geometry
(e) hedge (f) succession

II -Question 5. 火山の，火山性の
(a) imaginative
(b) incapabl
(c) institutional
(d) responsive
(e) selective (f) volcanic

II -Question 6. まっすぐに立っている
(a) absent
(b) aware
(c) central
(d) drunk
(e) historical (f) upright

II -Question 7. 電子レンジ
(a) auction
(b) aura
(c) chord
(d) container
(e) microwave (f) rivalry

II -Question 8. 余分な
(a) automatic
(b) extra
(c) honest
(d) legal
(e) sharp (f) smooth

II-Question 9. 生の（なまの），加工していない
(a) curious
(b) equal
(c) independent
(d) raw
(e) social (f) steady

II Q Question 10. 大工
(a) brow
(b) carpenter
(c) closet
(d) eyelid
(e) niece (f) tailor

II-Question 11.（犬や猫の)手
(a) anniversary
(b) biography
(c) paw
(d) postage
(e) resemblance (f) simplicity

II-Question 12. かたわらへよける
(a) deepen
(b) dissatisfy
(c) imprint
(d) pinpoint
(e) shuffle (f) sidestep

II -Question 13. 様々な色の石やガラスの小片を組み合わせた模様
(a) cock
(b) documentary
(c) hose
(d) mosaic
(e) oyster (f) seller

II -Question 14. 中立の
(a) dense
(b) logical
(c) neutral
(d) partial
(e) residential (f) spiritual

II -Question 15 . 石油
(a) capability
(b) continuity
(c) illusion
(d) petroleum
(e) resident (f) stupidity 
II-Question 16. 緊急事態
(a) apparatus
(b) boundary
(c) ceremony
(d) emergency
(e) horizon (f) sympathy

II -Question 17. 美術館
(a) charity
(b) distribution
(c) faculty
(d) gallery
(e) session (f) symphony

II-Question 18. 購入する，買う
(a) alternate
(b) collapse
(c) fetch
(d) pat
(e) purchase
(f) resume

II -Question 19. 有機体
(a) accumulation
(b) equality
(c) heritage
(d) identification
(e) organism (f) pulse

II -Question 20． 投資する
(a) admire
(b) cease
(c) celebrate
(d) construct
(e) invest (f) urge

II-Question 21. 切り倒す
(a) admit
(b) deny
(c) dine
(d) fell
(e) inquire (f) rescue

II-Question 22. 根本的に，本質的に
(a) aptly
(b) economically
(c) fundamentally
(d) genuinely
(e) immensely (f) radically

II-Question 23 . 徐々に
(a) gradually
(b) nearby
(c) necessarily
(d) occasionally
(e) solely (f) technically

II -Question 24. 遺伀学者
(a) astronomer
(b) censor
(c) entrepreneur
(d) geneticist
(e) plotter (f) rescuer

II-Question 25. 弱い，衰弱した
(a) feeble
(b) frontal
(c) literal
(d) surgical
(e) tidal (f) tribal

II -Question 26. 誤った管理，不始末
(a) antiquity
(b) cholesterol
(c) daisy
(d) mismanagement
(e) paradox (f) toughness

II -Question 27. 群れ
(a) complaint
(b) cone
(c) flock
(d) leadership
(e) temptation (f) transition

II-Question 28. 歩きまわる，ぶらつく
(a) coincide
(b) insulate
(c) marvel
(d) overwhelm
(e) roam (f) wring

II-Question 29. 無効の，～を欠いている
(a) affirmative
(b) ceramic
(c) intolerable
(d) narcotic
$\begin{array}{ll}\text { (e) psychiatric (f) void } & \end{array}$

II-Question 30. 財政上の, 会計の
(a) fiscal
(b) mortal
(c) productive
(d) republican
(e) sunny (f) underground

II -Question 31. 遗伝
(a) flexibility
(b) heredity
(c) presidency
(d) scrutiny
$\begin{array}{ll}\text { (e) specialty } & \text { (f) testimony }\end{array}$

II-Question 32. 施行, 執行
(a) anesthesia
(b) bait
(c) enforcement
(d) pretext
(e) propensity (f) protocol 
FORM III

日本語の意味を表す英語を（a)〜(f)の中から選び，その番号を解答用紙に記入せよ。

III-Question 1. 心理学
(a) billion
(b) bundle
(c) explanation
(d) flavor
(e) lightning (f) psychology

III-Question 2. かすみ，もや
(a) barn
(b) existence
(c) heap
(d) manufacturer
$\begin{array}{ll}\text { (e) mist } & \text { (f) vessel }\end{array}$

III-Question 3. 憎む
(a) appoint
(b) forgive
(c) hate
(d) pray
(e) seize
(f) spread

III-Question 4. 気がついて
(a) absent
(b) aware
(c) central
(d) drunk
$\begin{array}{ll}\text { (e) historical (f) upright } & \end{array}$

III-Question 5. 海岸
(a) benefit
(b) coast
(c) discipline
(d) division
(e) soap (f) truth

II-Question 6. 交響曲
(a) charity
(b) distribution
(c) faculty
(d) gallery
(e) session (f) symphony

III-Question 7. 分かれた，分離した
(a) bright
(b) frequent
(c) initial
(d) safe
$\begin{array}{ll}\text { (e) separate (f) urgent } & \end{array}$

III-Question 8. 好奇心の強い
(a) curious
(b) equal
(c) independent
(d) raw
$\begin{array}{ll}\text { (e) social (f) steady } & \end{array}$

m-Question 9. ことばの，言語の
(a) administrative
(b) atomic
(c) concrete
(d) frank
(e) linguistic (f) singular

III-Question 10. 天火(調理器具)
(a) bean
(b) fishermen
(c) ceiling
(d) margin
(e) oven (f) ray

III-Question 11. 優雅な，しとやかな
(a) constitutional
(b) emphatic
(c) graceful
(d) monotonous
$\begin{array}{ll}\text { (e) wasteful (f) yearly } & \end{array}$

III-Question 12. 再び始める
(a) alternate
(b) collapse
(c) fetch
(d) pat
(e) purchase (f) resume

II-Question 13. 実際に
(a) actually
(b) anyhow
(c) completely
(d) indeed
$\begin{array}{ll}\text { (e) somewhere (f) whenever } & \end{array}$

II-Question 14.おんどり
(a) cock
(b) documentary
(c) hose
(d) mosaic
(e) oyster (f) seller

III-Question 15. とにかく
(a) actually
(b) anyhow
(c) completely
(d) indeed
(e) somewhere
(f) whenever 
田-Question 16．回復すること，復旧
(a) claw
(b) collision
(c) courtesy
(d) epoch
(e) mischief (f) restoration

III-Question 17, 是認, 賛成
(a) approval
(b) contract
(c) democracy
(d) institution
(e) recall (f) wheat

III-Question 18． 仲直りさせる
(a) conclude
(b) hinder
(c) murmur
(d) reconcile
(e) stagger (f) weave

四·Question 19. ぐるぐる巻く，渦巻き
(a) blink
(b) chuckle
(c) heighten
(d) repel
$\begin{array}{ll}\text { (e) sob (f) whirl } & \end{array}$

III-Question 20. 憲法の，合憲の
(a) constitutional
(b) emphatic
(c) graceful
(d) monotonous
(e) wasteful (f) yearly

III-Question 21. 陶器の
(a) affirmative
(b) ceramic
(c) intolerable
(d) narcotic

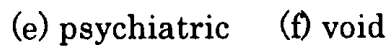

III-Question 22. 半狂乱となった, 血迷った
(a) adjective
(b) collective
(c) considerate
(d) eloquent
(e) frantic (f) genetic

III-Question 23，階級組織，階級制度
(a) breakthrough
(b) hierarchy
(c) landmark
(d) liaison
(e) maxim (f) protocol

III-Question 24. 死ぬことになっている，死を免れない
(a) fiscal
(b) mortal
(c) productive
(d) republican
(e) sunny (f) underground

III-Question 25，急慢，不注意
(a) breakthrough
(b) hierarchy
(c) landmark
(d) liaison
(e) maxim (f) negligence

II-Question 26. しきりに勧める
(a) admire
(b) cease
(c) celebrate
(d) construct
(e) invest (f) urge

III-Question 27. 競争, 対抗
(a) auction
(b) aura
(c) chord
(d) container
(e) microwave (f) rivalry

III-Question 28. 包む，覆う
(a) dodge
(b) envelop
(c) flop
(d) flush
$\begin{array}{ll}\text { (e) perch (f) } \operatorname{sip} & \end{array}$

III-Question 29．混乱させる，分裂させる
(a) brood
(b) clog
(c) disrupt
(d) distrust
(e) prosecute (f) wade

III-Question 30. 色, 色合い
(a) cadence
(b) composure
(c) hue
(d) influx
(e) junk (f) quirk

III-Question 31. 演繹（えんえき），控除
(a) deduction
(b) dwarf
(c) limestone
(d) plague
(e) plank (f) relevance

III-Question 32. 性質, 気質
(a) affiliation
(b) deprivation
(c) disposition
(d) injunction
(e) recession (f) remission 